\title{
THE EFFECTS OF HYDRATED LIME ON THE LINEAR SHRINKAGE, FREE SWELL AND SOIL SUCTION OF THE TROPICAL CLAY SOILS
}

\author{
Adil A. M. Elhassan ${ }^{1}$, Ahmed M. Elsharief ${ }^{2}$, Awad E. M. Mohamed ${ }^{3}$, Wael W. AL- Buzz \\ ${ }^{l}$ Department of civil Engineering, College of Engineering, Taif University, Kingdom of Sudi Arabia\& College of \\ Engineering, Sudan University of Science and Technology, Khartoum, Sudan \\ ${ }^{2}$ Building and Road Research Institute, University of Khartoum, Address: Khartoum, P.O.Box 321, Sudan \\ ${ }^{3}$ Building and Road Research Institute, University of Khartoum, Address: Khartoum, P.O.Box 321, Sudan \\ ${ }^{4}$ Department of Civil Engineering, College of Engineering, Taif University, Kingdom of Saudi Arabia
}

\begin{abstract}
The effects of hydrated lime on the linear shrinkage, free swell and soil suction of the six tropical clay soils were studied. Additional tests were conducted in the effects of lime on matric suction of swelling soils. It was found that all the tropical clay soils reacted with hydrated lime. The results showed that the addition of lime to tropical clay soils decreased their linear shrinkage and free swell and therefore decreases their shrink-swell potential. Matric suction of swelling clay soils decreased with the addition of lime and with the increase in lime content.
\end{abstract}

Keywords: Stabilization, Linear Shrinkage, Free Swell, Suction

\section{INTRODUCTION}

Tropical clay soils are principally the product of chemical weathering. Many factors add to the complex process of weathering in tropical environments amongst which are climate, composition and texture in the parent rock, topographical features, type and amount of vegetation cover and time (Morin, W.J. and Todor, P.C., 1970).

Sudan is a developing country. Extensive black cotton clay plains known as vertisols cover most of its land. These plains witness most of the development projects. Lateritic soils are found in the southern parts of the Sudan and in the Republic of South Sudan where rainfall rate is high and vegetation cover is rich (Elsharief, A.M. and Mohamed, S.A., 2000). Large residential areas of the clay plains of Sudan become isolated for several weeks during the rainy season. Major challenges are facing engineers when constructing roads on the swelling clay plains. Likewise, the very poor workability of the sub-grade when wetted, it's very low strength when saturated and the scarcity in alternative natural construction road materials (embankment, base and sub-base materials).

Today stabilization of tropical clay soils by adding hydrated lime is a widely used technique all over the world to improve its use in construction. It is used in road construction to improve sub-bases and sub-grades, for embankments, as soil exchange in unstable slopes, as backfill for bridge abutments and retaining walls, as canal linings, for improvement of soil beneath foundation slabs and for lime piles (Anon, 1990).

\section{MATERIALS AND METHODS}

\subsection{Materials}

Six tropical clay soil samples were selected to cover the central, eastern, mid-eastern and southern clay plains of Sudan taking into consideration variation in mineral composition of the clay (Montmorillonite/illite/kaolinite). These soil samples were obtained from the depth (between 0.5 to $3.0 \mathrm{~m}$ ). The first sample was obtained from Khartoum state, the second sample from sinnar town (Blue Nile), the third from Alfao town, the fourth from Rabak town (White Nile); the fifth sample from Wau Tumbora in South Sudan whereas the sixth sample was obtained from Unity State in Southern Sudan. the mineralogical characteristics of each soil samples; black cotton soils, lateritic ...etc presented in Table 1.

Table -1: XRD test results of the untreated six tropical soil samples

\begin{tabular}{|l|l|l|l|l|l|l|}
\hline \multirow{2}{*}{$\begin{array}{l}\text { Sam } \\
\text { ple } \\
\begin{array}{l}\text { Desi } \\
\text { gnat } \\
\text { ion }\end{array}\end{array}$} & Source & $\begin{array}{l}\text { Smect } \\
\text { ite\% }\end{array}$ & $\begin{array}{l}\text { Kaolinit } \\
\text { e\% }\end{array}$ & $\begin{array}{l}\text { Illite } \\
\%\end{array}$ & $\begin{array}{l}\text { Chlo } \\
\text { rite } \\
\%\end{array}$ & $\begin{array}{l}\text { Sm } \\
\text { e/Ill } \\
\text { i\% }\end{array}$ \\
\hline K1 & $\begin{array}{l}\text { Khartou } \\
\text { m }\end{array}$ & 61 & 29 & 10 & 00 & 00 \\
\hline S2 & Sinnar & 86 & 13 & 01 & 00 & 00 \\
\hline F3 & Alfao & 90 & 10 & 00 & 00 & 00 \\
\hline R4 & Rabak & 64 & 24 & 8.5 & 00 & 3.5 \\
\hline T5 & Tumbora & 00 & 89 & 00 & 11 & 00 \\
\hline A6 & Abyei & 29 & 61 & 06 & 00 & 04 \\
\hline
\end{tabular}


The hydrated lime used in this study was produced by heating high quality limestone obtained from Butana in eastern Sudan at 900 0C in the electrical furnace to produce quick lime. Water was added to the quick lime to produce hydrated lime $\left(\mathrm{Ca}(\mathrm{OH})_{2}\right)$.

\subsection{Linear Shrinkage}

The linear shrinkage test consists of placing a paste of soil passing the No. 40 sieve at its liquid limit moisture content in the of linear shrinkage mould, dry it first in air for 24 hour and then complete the drying in the oven at temperature of $105{ }^{\circ} \mathrm{C}$ to $110{ }^{\circ} \mathrm{C}$ to get completely dry sample. After it had dried, the final length of the soil is measured (Figure 1).The sample inside the mould loses moisture due to drying from the top surface, which has the maximum shrinkage. The shrinkage amount, decreases with the depth inside the mould so that the top surface will lie under tension stresses due to shrinkage also the tension will decrease with depth. For the balancing of the tension stresses at the top surface, compression stresses will generate at the bottom of the sample that may illustrate the hogging phenomenon shown in Figure 2 for some samples at the end of the test.

Two different parentages were added to each soil samples (by weight) and left for 2 hours and 7 days in sealed plastic bags to cure and obtain homogeneous paste. The percentages of lime were $3.5 \%$ and $7 \%$ for $\mathrm{K} 1$ sample, $3.5 \%$ and $7 \% \%$ for $\mathrm{S} 2$ sample, $3 \%$ and $6.5 \%$ for $\mathrm{F} 3$ sample, $3 \%$ and $6 \%$ for Ra4 sample, $2 \%$ and $4 \%$ for $\mathrm{T} 5$ sample and $2.5 \%$ and $5.5 \%$ for A6 soil sample. Linear shrinkage is the ratio of the change in length to the initial length, expressed as a percentage. The results are shown in Table 2 .

Table -2: Linear shrinkage of natural and stabilized soil

\begin{tabular}{|l|l|l|l|}
\hline \multicolumn{4}{|c}{ samples (curing time 2 hours) } \\
\hline \multirow{4}{*}{$\begin{array}{l}\text { Sample } \\
\text { Kesignation }\end{array}$} & Lime\% & $\begin{array}{l}\text { LS (2 hours } \\
\text { of curing } \\
\text { time) }\end{array}$ & $\begin{array}{l}\text { LS (7 days } \\
\text { of curing } \\
\text { time) }\end{array}$ \\
\hline \multirow{4}{*}{ S2 } & 0.0 & 23.52 & 23.52 \\
\cline { 2 - 4 } & 3.5 & 10.30 & 6.5 \\
\cline { 2 - 4 } & 7.0 & 8.76 & 3.3 \\
\hline \multirow{5}{*}{ F3 } & 0.0 & 22.92 & 22.92 \\
\cline { 2 - 4 } & 3.5 & 11.5 & 7.8 \\
\cline { 2 - 4 } & 7.0 & 6.20 & 4.0 \\
\hline \multirow{4}{*}{ R4 } & 0.0 & 19 & 19 \\
\cline { 2 - 4 } & 3.0 & 9.90 & 6.0 \\
\cline { 2 - 4 } & 6.5 & 5.10 & 4.2 \\
\hline \multirow{3}{*}{ T5 } & 0.0 & 19.29 & 19.29 \\
\cline { 2 - 4 } & 3.0 & 12.6 & 8.1 \\
\cline { 2 - 4 } & 6.0 & 9.1 & 5.3 \\
\hline \multirow{4}{*}{ A6 } & 0.0 & 16.0 & 16.0 \\
\cline { 2 - 4 } & 2.0 & 6.5 & 4.4 \\
\cline { 2 - 4 } & 4.0 & 3.1 & 1.9 \\
\hline & 0.0 & 20.0 & 20.0 \\
\cline { 2 - 4 } & 2.5 & 11.1 & 7.9 \\
\cline { 2 - 4 } & 5.5 & 4.2 & 3.0 \\
\hline
\end{tabular}

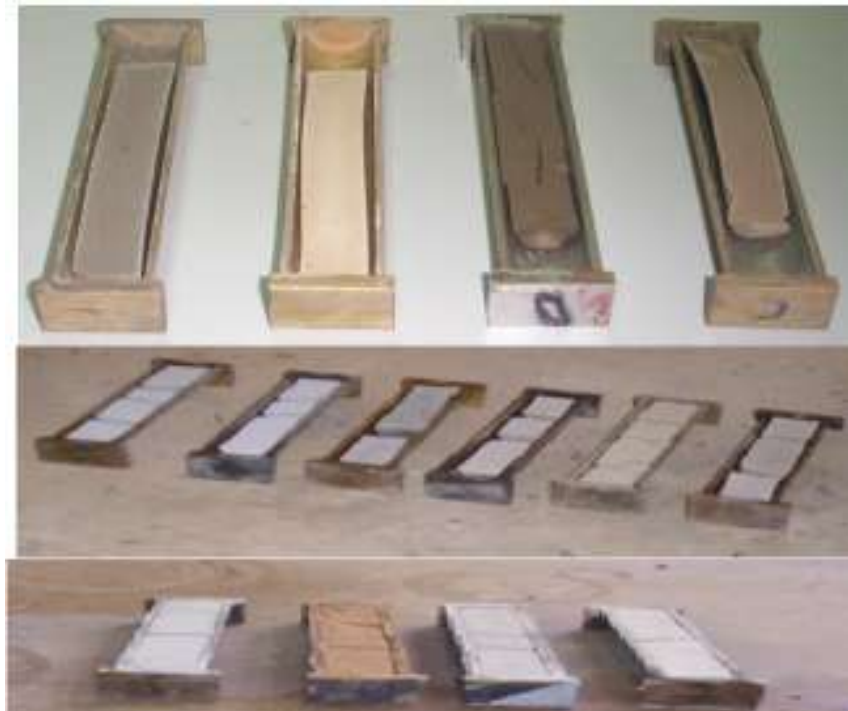

Fig -1: Final length of LS for different samples after oven drying

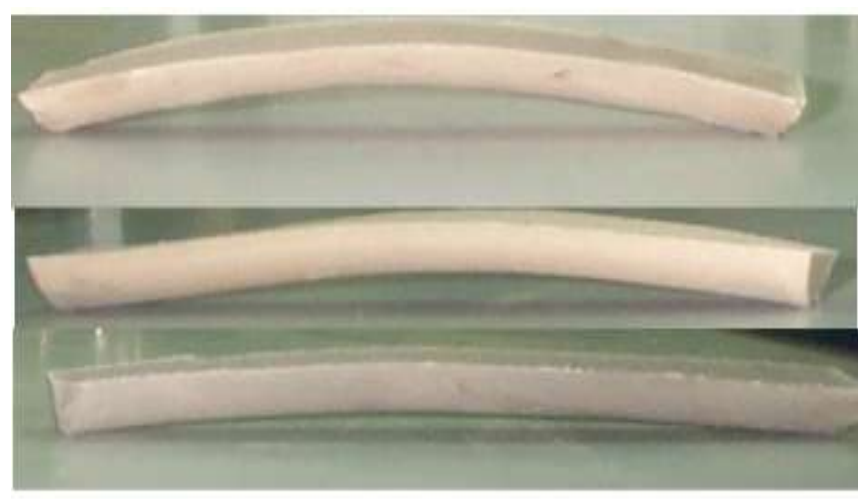

Fig -2: The hogging phenomenon for some soil samples

\subsection{Free Swell}

The free swell test consists of placing a known volume of dry soil passing the No.40 sieve into a graduated cylinder filled with water and measuring the swelled volume after it had completely settled. Lime was added in two parentages for all soil samples (by weight) and left for 2 hours and 7 days in sealed plastic bags to cure and obtain homogeneous paste. The percentages of lime was $3.5 \%$ and $7 \%$ for $\mathrm{K} 1$ soil, $3.5 \%$ and $7 \% \%$ for $\mathrm{S} 2$ soil, $3 \%$ and $6.5 \%$ for $\mathrm{F} 3$ soil, $3 \%$ and $6 \%$ for R4 soil, $2 \%$ and $4 \%$ for $\mathrm{T} 5$ soil and $2.5 \%$ and $5.5 \%$ for A6 soil sample. The free swell of the soil was the ratio of the change in volume to the initial volume expressed as a percentage. The results are shown in Table 3 for the 2 hours and 7 days curing times.

Table -3: Free swell for natural and stabilized soil samples (curing time 2 hours)

\begin{tabular}{|l|l|l|l|}
\hline $\begin{array}{l}\text { Sample } \\
\text { Designation }\end{array}$ & Lime\% & $\begin{array}{l}\text { FS (2 hours } \\
\text { of curing } \\
\text { time })\end{array}$ & $\begin{array}{l}\text { FS (7 days of } \\
\text { curing time) }\end{array}$ \\
\hline \multirow{3}{*}{ K1 } & 0.0 & 163 & 163 \\
\cline { 2 - 4 } & 3.5 & 61 & 51 \\
\cline { 2 - 4 } & 7.0 & 36 & 20 \\
\hline
\end{tabular}




\begin{tabular}{|l|l|l|l|}
\hline \multirow{4}{*}{ S2 } & 0.0 & 160 & 160 \\
\cline { 2 - 4 } & 3.5 & 81 & 66 \\
\cline { 2 - 4 } & 7.0 & 38 & 19 \\
\hline \multirow{4}{*}{ F3 } & 0.0 & 167 & 167 \\
\cline { 2 - 4 } & 3.0 & 83 & 64 \\
\cline { 2 - 4 } & 6.5 & 32 & 18 \\
\hline \multirow{5}{*}{ R4 } & 0.0 & 122 & 122 \\
\cline { 2 - 4 } & 3.0 & 90 & 71 \\
\cline { 2 - 4 } & 6.0 & 49 & 29 \\
\hline \multirow{5}{*}{ T5 } & 0.0 & 90 & 90 \\
\cline { 2 - 4 } & 2.0 & 41 & 29 \\
\cline { 2 - 4 } & 4.0 & 26 & 13 \\
\hline \multirow{4}{*}{ A6 } & 0.0 & 105 & 105 \\
\cline { 2 - 4 } & 2.5 & 70 & 55 \\
\cline { 2 - 4 } & 5.5 & 32 & 21 \\
\hline
\end{tabular}

\subsection{Soil Suction}

The soil suction test was carried out on untreated and treated F3 soil sample at optimum lime content $(6.5 \%)$ and $50 \%$ of the optimum lime content (3\%). Mechanical dry mixing method was used in mixing lime and soil. Water was added and the samples were carefully mixed and left to cure for two hour in sealed plastic bags to obtain homogeneous mix. The filter paper calibration curve for the batch of Whatman No. 42 filter papers (ASTM D5298, 2000) shown in Figure 3 was used in these experiments.

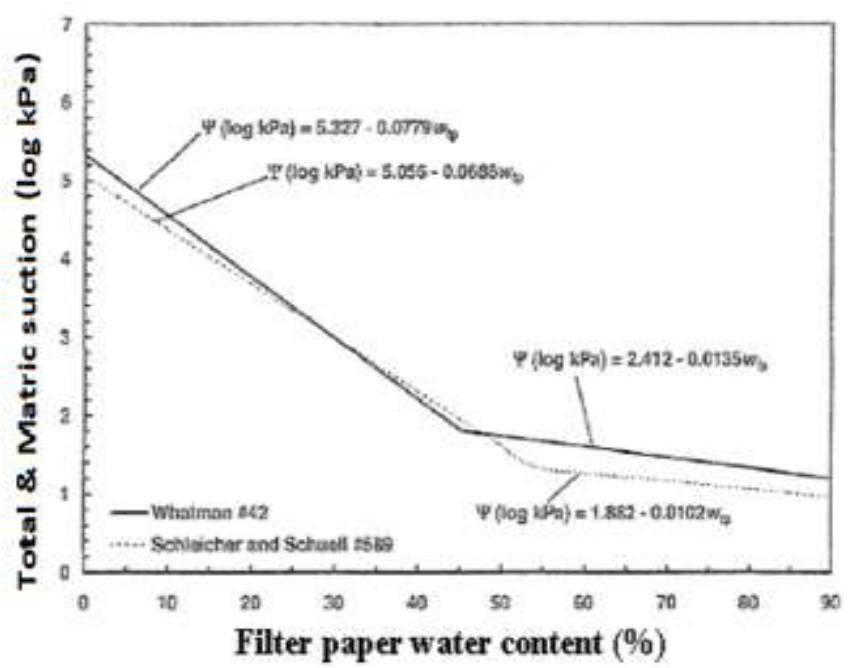

Fig -3: Calibration curves for Whatman \#42 and Schleicher and Schuell \#589 filter papers (ASTM D5298, ASTM 2000)

The soil samples were prepared for the filter paper $(5.5 \mathrm{~cm}$ in diameter) and odometer testing using different moisture contents (dry of optimum and wet of optimum). Mechanical cutter was used for dividing soil samples in two equal pieces. Tweezers were used to place the sandwiched filter papers on top of the soil sample and put the other half of the soil sample on top (Figure 4).

The two pieces of the soil sample were taped using electrical plastic tape to keep them together to ensure compatibility and then PVC O-ring was placed on the top sample surface

for measuring total suction of the soil sample. Two Whatman No. 42 filter papers were placed on the top of the O-ring and then the lid (cover) was placed and properly tightened. All the prepared samples were placed and kept in glass jars as shown in Figure 4 mainly to prevent any moisture change between the air in and outside of the jar. The glass jars were perfectly presented in a well - isolated plastic container for 7 days. This process was done mainly to ensure temperature-controlled environment and consequently satisfying suction equilibrium.
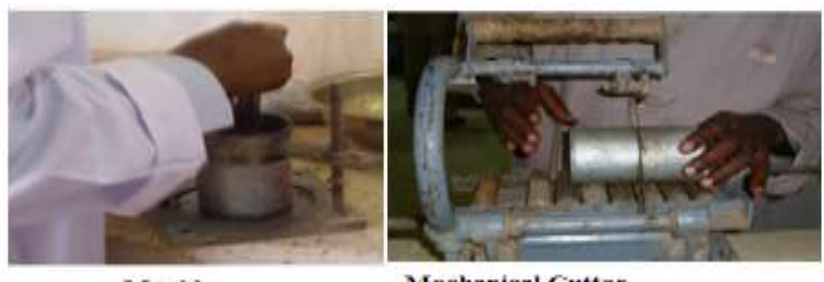

Mould

Mechanical Cutter

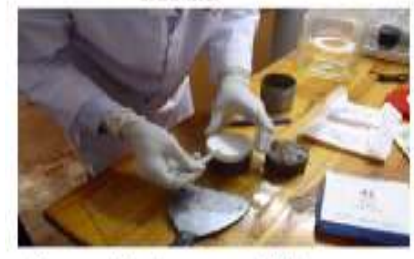

Two soll pieces and fite

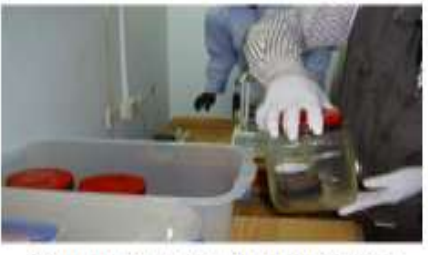

Sample on glass (min one week

Fig -4: Soil suction procedure

After 7 days of equilibrium period; samples were taken out of the glass jars then the filter paper swiftly weighted using sensitive balance of $0.0001 \mathrm{~g}$ accuracy. All filter paper were oven dried for 10 hours, and then their dry weights were measured. The resulted moisture of filter paper was determined for matric suction according to Whatman No. 42 calibration curve shown in Figure 3. The test was carried out accordance with ASTM D5298 test procedures. The test obtained results for matric suction are given in Table 4 .

Table -4: Matric suction test results for natural and stabilized F3 soil sample

\begin{tabular}{|l|l|l|l|l|l|}
\hline \multicolumn{2}{|l|}{ F3 + 0 lime } & \multicolumn{2}{l|}{ F3 + $3 \%$ lime } & \multicolumn{2}{l|}{ F3 6.5 lime } \\
\hline $\begin{array}{l}\text { Soil } \\
\text { M.C\% }\end{array}$ & $\begin{array}{l}\text { Suction } \\
\text { (Kpa) }\end{array}$ & $\begin{array}{l}\text { Soil } \\
\text { M.C\% }\end{array}$ & $\begin{array}{l}\text { Suction } \\
\text { (Kpa) }\end{array}$ & $\begin{array}{l}\text { Soil } \\
\text { M.C\% }\end{array}$ & $\begin{array}{l}\text { Suction } \\
\text { Kpa })\end{array}$ \\
\hline 22.5 & 8145 & 22.8 & 6713 & 23.1 & 4890 \\
\hline 25.8 & 6112.5 & 25.6 & 5316 & 26.3 & 3110 \\
\hline 28.0 & 4800 & 28.2 & 3918 & 29.0 & 2010 \\
\hline 30.0 & 3619.7 & 30.4 & 2810 & 31.2 & 1115 \\
\hline 32.0 & 2450 & 32.7 & 1671 & 33.6 & 720 \\
\hline 34.1 & 1535 & 34.8 & 954 & 36.0 & 410 \\
\hline 36.3 & 1050 & 36.9 & 628 & 38.1 & 265 \\
\hline
\end{tabular}

\section{RESULTS AND DISCUSSION}

\subsection{Effect of Lime on Linear Shrinkage (LS)}

The objective of this test was to study the effects of adding different percentages of hydrated lime on the shrinkage properties of the six soil samples. The results shown in Table 2 and plotted in Figure 5 and Figure 6 for all six soil 
samples, showed that addition of lime to the natural samples decreased their linear shrinkage. The LS for the stabilized samples continued to decrease with increase in lime content up to optimum hydrated lime. The LS decreased by more than $50 \%$ for 2 hours curing and $70 \%$ for 7 days curing for OLC. It can be seen from Figure 5 and Figure 6 that the kaolinitc soil (T5 soil) gave the lowest value of linear shrinkage compared to swelling soils when treated at OLC after curing time of two hours and seven days.

In addition, results indicated that the linear shrinkage decreased with increase in lime content (Rahmatalla, H. H 2005). The relationships between the linear shrinkage and the lime content represent nonlinear retarding formulae (Figure 5 and Figure 6). This is true for curing time of two hours and seven days and all samples except, R4 sample at curing time of two hours is showing direct linear inverse proportionality between the linear shrinkage and the lime content. For seven days curing time, it was noted that linear shrinkage was constant after a certain value of the lime content.

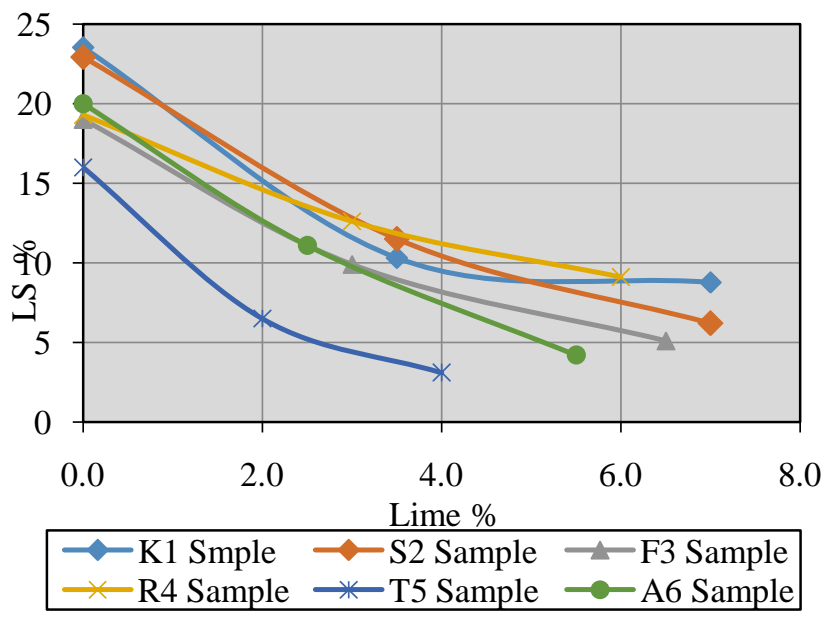

Fig -5: Linear shrinkage vs. lime (curing time, 2 hours)

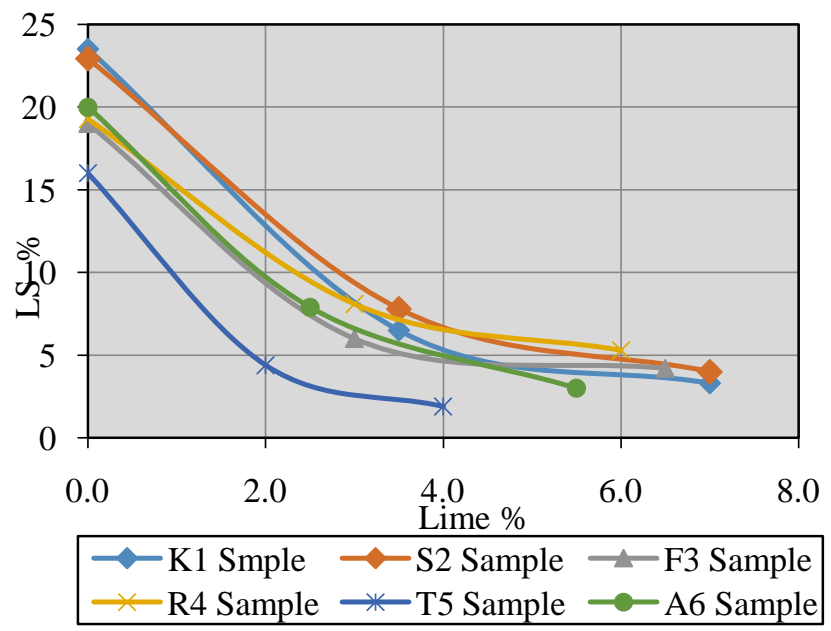

Fig -6: Linear shrinkage vs. lime (curing time, 7 days)

\subsection{Effect of lime on Free Swell}

This test attempted to study the effect of lime on the swelling properties of the six soil samples. From the results shown in Table 3 and plotted in Figures 7 and 8 for all six soil samples it is clear that addition of lime to the natural samples decreased their free swell. Addition of OLC showed significant effects on decreasing free swell after curing for 2 hours and 7 days. Most of the relationships between the free swell and the lime content constitute nonlinear inverse formulae (Khattab and M. Fleureau. J. M 2007). The exception in the soil samples from R4 and A6, which are showing direct linear inverse proportionality relationships.

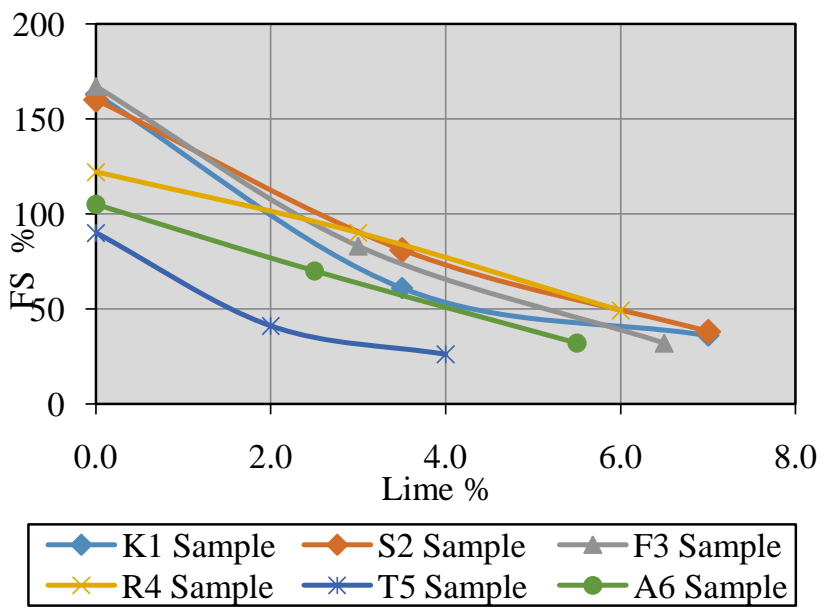

Fig -7: Free swell vs. lime (curing time, 2 hours)

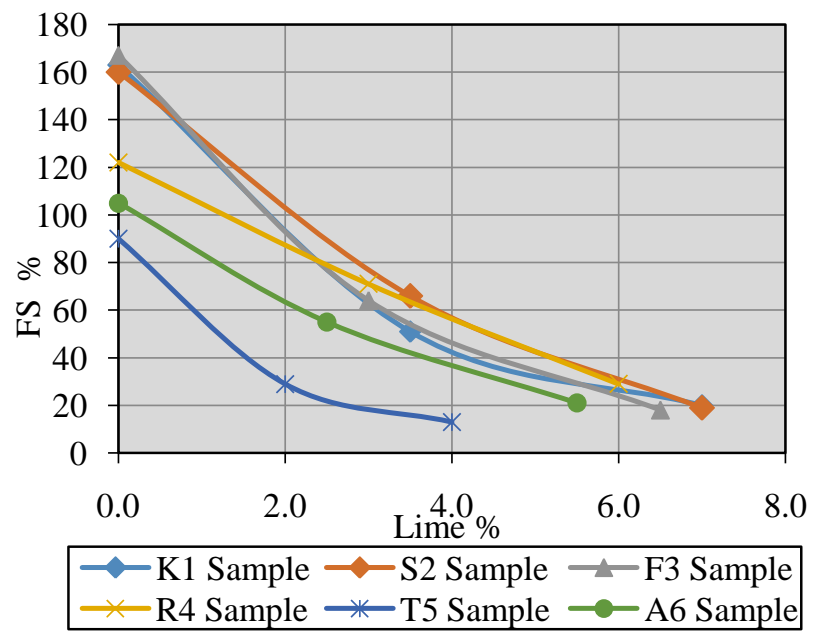

Fig -8: Free swell vs. lime (curing time, 7 days)

\subsection{Effect of Lime on Soil Suction}

In this study, soil suction test was carried out to measure the matric soil suction component of F3 soil treated with OLC and $50 \%$ of OLC. This test was carried out to study the effect of lime addition on matric suction of a stabilized montmorillonitic soil sample. Soil suction tests were performed using the filter paper method according to (ASTM, 2000) test method. The filter paper moisture 
contents were converted to matric suction using the calibration curves in ASTM (ASTM D5298, ASTM 2000).

The addition of hydrated lime significantly reduced the matric soil suction for the same water content as shown in Table 4 and Figure 9, while it was found that for the same moisture content, the matric suction is reduced by the increase of lime content; the minimum is always reached with highest lime content, which is the OLC (Elhassan.A. M, 2014).

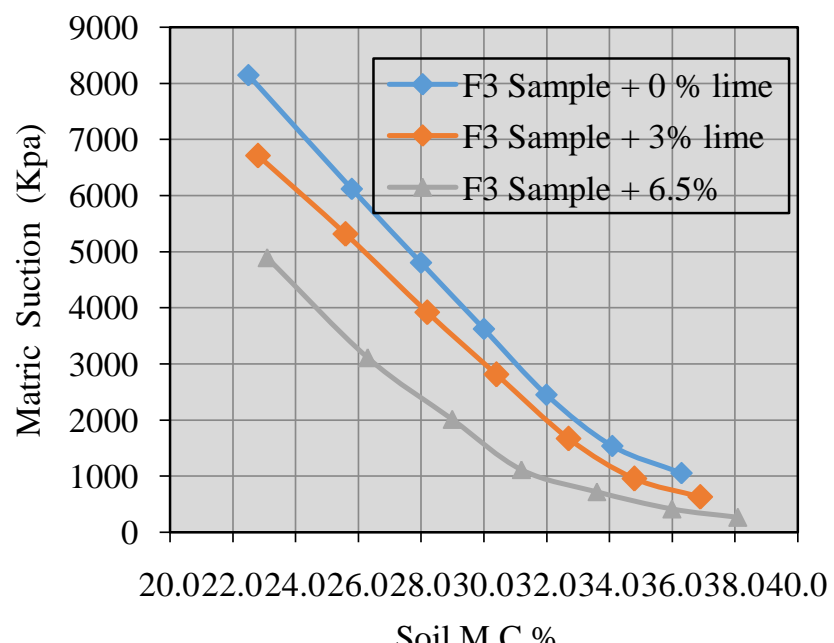

Fig -9: Plotting matric soil suction versus lime content (F3 soil sample)

\section{CONCLUSION}

According to the results of experiments carried out on the six tropical soil samples, the addition of lime affected the values of engineering properties of the six tropical soils such as LS and FS. Considerable differences in the results of LS, and FS before and after adding lime were observed. Distinct improvement or effect was noticed when optimum hydrated lime content or more of lime was added to the six tropical soil samples (Adil A. M., and Ahmed M. Elsharief, 2015).

Addition of lime caused remarkable reduction in LS and FS for the treated tropical soil samples. Significant effects were notices after curing for 2 hours and 7days of curing time. The limit recommended by Transport Research Laboratory (TRL, 1993) for FS ranged from 20 to 40 for sub-grade soils.

The present study showed that the addition of lime to tropical clay soils decreased their linear shrinkage and free swell and therefore decreases their shrink-swell potential to the limits that satisfy the requirements for road subgrade and pavement materials. The Effects of Lime on Matric Suction for A montmorillonitic Soil. Matric suction of swelling clay soils is found to decrease significantly with the addition of lime and with the increase in lime content (Adil A. M., and Ahmed M. Elsharief, 2016).

\section{ACKNOWLEDGEMENT}

First of all we would like to express our great thanks to God Almighty for helping use to finish this humbly research, and this is our pleasure to express our special thanks to Scientific Research Deanship at Taif University for their full support to the scientific research at the university. Our thanks extended to Building and road research institute (BRRI) -University of Khartoum. We are also grateful to all people and colleagues who supported us with data that we needed to complete the research.

\section{REFERENCES}

[1] Morin, W.J. and Todor, P.C. (1970), "Laterite and lateritic soils and other problem soils of the tropics", Vol 2.

[2] Elsharief, A.M. and Mohamed, S.A. (2000), "Technical and economical viability of lime stabilization of expansive soils for road construction in Sudan", Sudan Engineering Society Journal", Vol. 47 No. 38,p 5-16.

[3] Anon (1990), "Lime Stabilization Manual", British Aggregate Construction Materials Industry, London.

[4] ASTM D 5298-94 (2000),"Standard test method for measurement of soil potential (suction) using filter paper," Vol. 4.08. D-18 Committee on Soils and Rocks. West Conshohocken, .p. 1082-1087.

[5] Rahmatalla, H. H (2005), "Shrinkage Behavior of Expansive Soils from Sudan", M.Sc. Thesis, University of Khartoum, Sudan.

[6] Khattab, S. A. A. Al-Mukhtar. M. Fleureau. J. M (2007), "Long-term Characteristics of a Lime Treated Plastic Soil”, Materials in Civil Engineering, 19(4), p 358-366.

[7] Elhassan.A. M (2014)., “ Lime stabilization of tropical clay soils from Sudan,"PhD. Thesis, University of Khartoum, Sudan.

[8] Adil A. M., and Ahmed M. Elsharief (2015)., “ Engineering Properties of Lime Stabilized Swelling Soils from Sudan," International Journal of Science, Engineering and Technology Research (IJSETR), Volume 4, Issue 10.

[9] A.M. Elhassan1, A.M. Elsharief (2016),"Effect of Salinity on Hydrated Lime Stabilized Swelling Clay Soils from Sudan", IJREAT International Journal of Research in Engineering \& Advanced Technology, Volume 3, Issue 6.

[10] Overseas, Road.Note.31(1993),"Aguide to the Structural Design of Bitumen Surfaced Roads in Tropical Countries,'Transportation Research Laboratory. 